\title{
Chemical properties of an Oxisol after gypsum application
}

\section{Extrato de saturação e condutividade elétrica de um Latossolo vermelho eutroférrico após a gessagem}

\author{
Victor Roncaratti de Moraes $^{1 *}$; Thadeu Rodrigues de Melo; ${ }^{1}$ Osmar Rodrigues Brito ${ }^{2}$
}

\begin{abstract}
Gypsum utilization is a critical practice in agriculture because of the high solubility and consequent relative neutralization of subsurface toxic aluminum. However, it has been observed that in most cases, gypsum is being randomly utilized without scientifically established parameters or even the need to use it as a soil amendment at all. The objective of this study was to evaluate the chemical composition and electrical conductivity of an Oxisol's saturation extract under different gypsum doses $(0,1.0,2.0,4.0$, and $\left.8.0 \mathrm{Mg} \mathrm{ha}^{-1}\right)$. This experiment was conducted in a greenhouse environment. Soil columns $(\mathrm{V}=1.57$ $\mathrm{dm} 3)$ were filled with sifted $(2 \mathrm{~mm})$ soil collected from the upper layer $(0-20 \mathrm{~cm})$. The experimental design adopted was completely randomized with five repetitions. The treatments consisted of a $5 \times 2$ factorial through five gypsum doses $\left(0.0,1.0,2.0,4.0\right.$, and $8.0 \mathrm{Mg} \mathrm{ha}^{-1}$ of gypsum consisting of 224.1 $\mathrm{g} \mathrm{kg}^{-1} \mathrm{~S}, 314.8 \mathrm{~g} \mathrm{~kg}^{-1} \mathrm{CaO}$, and $\left.7 \mathrm{~g} \mathrm{~kg}^{-1} \mathrm{P} 2 \mathrm{O} 5\right)$ and two depth evaluations (0-10 and 10-20 cm). After the treatments, soil from both $0-10 \mathrm{~cm}$ and $10-20 \mathrm{~cm}$ layers was removed from the columns, sifted once $(2 \mathrm{~mm})$, and subjected to vacuum extraction to assess the saturation extract. The data acquired was processed and submitted to variance analysis (when due) and adjusted to regression equations when statistically relevant. Significant increases were observed for $\mathrm{Ca}, \mathrm{Mg}, \mathrm{K}, \mathrm{P}$, and $\mathrm{S}$, although $\mathrm{Al}, \mathrm{Si}$, and $\mathrm{pH}$ presented no statistically significant difference. The electrical conductivity value of this soil in particular is directly related to the gypsum dose.
\end{abstract}

Key words: Agricultural gypsum. Leaching. Salinization.

\section{Resumo}

A aplicação do gesso agrícola é importante na agricultura por sua alta solubilidade e consequente neutralização relativa do alumínio tóxico na camada superficial do solo. Entretanto, tem-se observado a ocorrência de aplicações com base em critérios aleatórios, sem embasamento científico coerente com a experimentação agrícola. O objetivo desse estudo foi avaliar a composição química e condutividade elétrica do extrato de saturação de um Latossolo Vermelho eutroférrico sob diferentes doses de gesso $\left(0 ; 1,0 ; 2,0 ; 4,0 \mathrm{Mg} \mathrm{ha}^{-1}\right)$. O experimento foi conduzido em ambiente de casa de vegetação. Colunas de solo $\left(\mathrm{V}=1,57 \mathrm{dm}^{3}\right)$ foram preenchidos com solo peneirado $(2 \mathrm{~mm})$ coletado na camada superficial $(0-20 \mathrm{~cm})$. O delineamento experimental utilizado foi inteiramente casualizado, com cinco repetições. Os tratamentos testados resultaram de um fatorial $5 \times 2 \mathrm{em}$ que os fatores foram cinco doses de gesso $\left(0,0-1,0-2,0-4,0\right.$ e $8,0 \mathrm{Mg} \mathrm{ha}^{-1}$ de gesso agrícola $\left(224,1 \mathrm{~g} \mathrm{~kg}^{-1}\right.$ de $\mathrm{S}, 314,8 \mathrm{~g} \mathrm{~kg}^{-1} \mathrm{de} \mathrm{CaO}$ e $7 \mathrm{~g} \mathrm{~kg}^{-1} \mathrm{de}$ $\left.\mathrm{P}_{2} \mathrm{O}_{5}\right)$ e 2 profundidades de amostragem $(0-10$ e 10-20 cm). Após os tratamentos, ambas as camadas de solo $(0-10 \mathrm{~cm}$ e $10-20 \mathrm{~cm})$ foram removidas das colunas, peneiradas $(2 \mathrm{~mm})$ e submetidas a extração à vácuo para obtenção do extrato de saturação. Os dados obtidos foram submetidos a análises de variância e ajustados às equações de regressão, quando diferiram estatisticamente. Enquanto os teores de Al, Si, e o pH do extrato de saturação do solo não foram influenciados, os teores de $\mathrm{Ca}, \mathrm{Mg}, \mathrm{K}, \mathrm{P}$ e S aumentam em função da aplicação superficial de doses de gesso agrícola. Após a aplicação de diferentes doses

1 Discentes, Programa de Pós-Graduação de Mestrado, Universidade Estadual de Londrina, UEL, Londrina, PR, Brasil. E-mail: victorrmoraes@hotmail.com; thadeurodrigues@hotmail.com

2 Prof. Dr., Departamento de Agronomia, UEL, Londrina, PR, Brasil. E-mail: osmar@uel.br

Author for correspondence 
de gesso agrícola, não ocorreram variações significativas nos teores de $\mathrm{P}, \mathrm{Si}, \mathrm{Al}$ e do $\mathrm{pH}$ da camada subsuperficial (10-20) do solo. A condutividade elétrica (CE) do extrato de saturação do solo estudado aumentou com o aumento das doses de gesso.

Palavras-chave: Gesso agrícola. Lixiviação. Salinização.

\section{Introduction}

Agricultural gypsum $\left(\mathrm{CaSO}_{4} \cdot 2 \mathrm{H}_{2} \mathrm{O}\right)$ is produced from apatite (phosphate rock) treated with sulfuric acid during the initial phase of phosphoric acid production. The obtained phosphoric acid is later used in phosphate fertilizer production as triple superphosphate (TSP), monoammonium phosphate (MAP), and diammonium phosphate (DAP).

According to Korndörfer (2008), agricultural gypsum presents solubility of approximately 2.0 $\mathrm{g} \mathrm{L}^{-1}$. Pavan (1984) notes that its use is important for areas where there are chemical impediments in subsurface layers due to free aluminum in solution, which limits plants' root system development.

The benefits of agricultural gypsum for soil management have been known for a long time. However, agricultural gypsum application is a technique that depends on research to better define methods for deciding doses as per the consequences of their use.

Previous studies offer divergent results. Forloni (2008) suggests applying doses of up to $32 \mathrm{t} \mathrm{ha}^{-1}$ of gypsum, based only on potential cation exchange capacity (CEC) increments observed, shoot biomass production, and yield of corn crop. Knowing that calcium ions in solution affect the estimation of potential CEC, it becomes evident that this method is inadequate for defining the need for gypsum in soils. On the other hand, suggestions such as those of Malavolta et al. (2006) indicate that gypsum doses should not exceed $25 \%$ of the recommended liming. According to Raij et al. (2008), gypsum should only be applied in areas with exchangeable $\mathrm{Al}$ above $40 \%$ and exchangeable Ca below $0.4 \mathrm{cmol}_{\mathrm{c}} \mathrm{dm}^{-3}$ in the $0-40 \mathrm{~cm}$ layer.

There is a need to evaluate, with better precision, the impacts of agricultural gypsum application on different soil attributes. According to Jalali and
Rowell (2009) and Maria et al. (1993), increased calcium concentration in soil solutions can promote leaching of potassium and other ions, generating an undesirable disequilibrium between soil base cations. However, Sousa et al. (2005) note that the high mobility of gypsum in the arable layers is associated with nutrients leaching to deeper layers, favoring crops' root development and reducing possible damage during drought periods. Farina et al. (1988) observed that gypsum surface application resulted in the increase of $\mathrm{Ca}, \mathrm{Mg}$, and $\mathrm{SO}_{4}-\mathrm{S}$ levels in subsurface soils.

In light of the need for new evaluations of the effects of agricultural gypsum on soil properties, this experiment aimed to evaluate electrical conductivity; $\mathrm{Ca}, \mathrm{Mg}, \mathrm{K}, \mathrm{S}, \mathrm{P}$, and $\mathrm{Al}$ levels; and $\mathrm{pH}$ of saturation extract of Red Latosol.

\section{Material and Methods}

The experiment was performed in a private laboratory situated in Londrina City, Paraná.

The soil used was collected at the surface layer (0$20 \mathrm{~cm}$ ) of a Red Latosol from Alvorada do Sul City, Paraná (Latitude: $-23^{\circ} 19^{\prime} 0.02^{\prime \prime} \mathrm{S}$ and Longitude: $\left.-51^{\circ} 10^{\prime} 37.33^{\prime \prime} \mathrm{W}\right)$, with the following physical and chemical attributes: $130 \mathrm{~g} \mathrm{~kg}^{-1}$ sand, $180 \mathrm{~g} \mathrm{~kg}^{-1}$ silt, $690 \mathrm{~g} \mathrm{~kg}^{-1}$ clay, $\mathrm{pH} \mathrm{H}_{2} \mathrm{O}=5.58, \mathrm{Ca}=8.84$ cmolc $\mathrm{dm}^{-3}, \mathrm{Mg}=2.33 \mathrm{cmolc} \mathrm{dm}^{-3}, \mathrm{~K}=0.37 \mathrm{cmolc} \mathrm{dm}^{-3}$, $\mathrm{CEC}_{\mathrm{pH} 7}=17.94 \mathrm{cmolc} \mathrm{dm}^{-3}, \mathrm{H}^{+}+\mathrm{Al}^{3+}=6.39 \mathrm{cmolc}$ $\mathrm{dm}^{-3}, \mathrm{Al}^{3+}=0.0 \mathrm{cmolc} \mathrm{dm}^{-3}, \mathrm{~S}_{-} \mathrm{SO}_{4}=5.13 \mathrm{mg} \mathrm{dm}^{-3}$, P-Mehlich $=12.46 \mathrm{mg} \mathrm{dm}^{-3}, \mathrm{P}-\mathrm{Rem}=19.66 \mathrm{mg}$, and $\mathrm{V}=64.3 \%$. Before experiment installation, soil was sieved using a $2.0 \mathrm{~mm}$ sieve and corrected by liming with calcite limestone and fertilizing with potassium chloride, aiming to increase $\mathrm{Ca}$ and $\mathrm{K}$ saturation to $65 \%$ and $5 \%$, respectively (KINSEY, 2009). Chemical analysis was performed after making these corrections (Table 1). 
Table 1. Results of soil chemical analysis after correction and before experiment installation.

\begin{tabular}{|c|c|c|c|c|c|c|c|c|c|c|c|c|c|}
\hline $\begin{array}{l}\mathrm{pH} \\
\mathrm{CaCl} 2\end{array}$ & $\begin{array}{l}\mathrm{pH} \\
\mathrm{H} 2 \mathrm{O}\end{array}$ & $\mathrm{Ca}^{2+}$ & $\mathrm{Mg}^{2+}$ & $\mathrm{K}^{+}$ & $\mathrm{H}^{+}+\mathrm{Al}^{3+}$ & $\mathrm{Al}^{3+}$ & $\begin{array}{c}\text { CEC } \\
\text { effective }\end{array}$ & $\begin{array}{l}\mathrm{CEC} \\
\mathrm{pH}_{7,00}\end{array}$ & $\begin{array}{l}\mathrm{V} \\
(\%)\end{array}$ & P-rem & $\mathrm{P}$ & $\mathrm{S}-\mathrm{SO}_{4}$ & $\begin{array}{c}\mathrm{Vp} \\
\left(\mathrm{m}^{3} \mathrm{~m}^{-3}\right)\end{array}$ \\
\hline & & - & - & - & $-\mathrm{cmol}_{\mathrm{c}} \mathrm{C}$ & $\mathrm{m}^{-3}-$ & --------- & - & & ------. & $-\mathrm{mg} \mathrm{d}$ & 3 ----- & \\
\hline 5.37 & 5.98 & 10.95 & 2.25 & 0.92 & $4.18^{c}$ & 0.00 & 14.13 & 18.31 & 77.15 & 19.89 & 14.54 & 6.04 & 0.2483 \\
\hline
\end{tabular}

$\mathrm{V}=$ Base saturation; P-rem = Remaining phosphorus; $\mathrm{Vp}=$ Volume of pores. Extractors: $\mathrm{KCl} 1 \mathrm{~N}\left(\mathrm{Ca}^{2+}, \mathrm{Mg}^{2+}, \mathrm{Al}^{3+}\right)$ Mehlich-1 $(\mathrm{P}$ and $\mathrm{K}), \mathrm{CH}_{3} \mathrm{COONH}_{4}\left(\mathrm{~S}-\mathrm{SO}_{4}\right)$.

The experimental design was completely randomized, with 5 replications. The tested treatments resulted in a $5 \times 2$ factorial, where 5 gypsum doses $\left(0.0,1.0,2.0,4.0\right.$, and $8.0 \mathrm{Mg} \mathrm{ha}^{-1}$ of agricultural gypsum comprising $224.1 \mathrm{~g} \mathrm{~kg}^{-1} \mathrm{~S}$ and $\left.314.8 \mathrm{~g} \mathrm{~kg}^{-1} \mathrm{CaO}\right)$ and 2 layers (0-10 and 20-30 cm) were evaluated.

The PVC columns used in this study were built using two pipes $100 \mathrm{~mm}$ in diameter and $100 \mathrm{~mm}$ tall. The pipes were connected using insulating tape, forming a column with a height of $200 \mathrm{~mm}$. Before filling with sieved earth (2.0 mm sieve), the columns were sealed with paraffin on the inner surface to avoid preferential flux in the soil-column interface. The bottom of the column was sealed using a plastic film with small holes $\left(1.0 \mathrm{~mm}^{2}\right)$ to drain the percolated water. The columns were filled with sieved earth to reach a density of $1.2 \mathrm{~g} \mathrm{dm}^{-3}$.

After filling the columns, gypsum was applied on the surface in the respective doses. In sequence, the columns were irrigated $\left(1000 \mathrm{~mL} \mathrm{~h}^{-1}\right)$ with deionized water using three times the total volume of pores. After complete drainage, the columns were allowed to stand for $24 \mathrm{~h}$. After this period, the columns were disassembled and the earth was air-dried for $24 \mathrm{~h}$. The 0-10 and 10-20 cm layers were separated and sent to the laboratory to carry out chemical analysis of the saturation extract (saturate-paste) extracted by vacuum in a Kitasato. In each saturation extract, the $\mathrm{Ca}, \mathrm{Mg}, \mathrm{K}, \mathrm{Al}, \mathrm{Si}, \mathrm{P}$, and $\mathrm{S}$ levels were quantified using an Argon inductively coupled plasma (ICPAES), as described in Montaser and Fassel (1976). Soil electrical conductivity and $\mathrm{pH}$ were evaluated in previously calibrated condutivimeter and $\mathrm{pH}$ meter (CPRM, 2007).

Analysis of variance (ANOVA) was performed using SISVAR 4.3 and, when necessary, means were compared using Tukey test at $5 \%$ or polynomial regressions were adjusted.

\section{Results and Discussion}

No change in phosphorous content was observed between the layers, indicating that the tested doses affected phosphorous mobilization, despite the high addition of sulfate (Table 1). However, linear increases in $\mathrm{P}$ levels of the saturation extract as a function of gypsum doses were observed (Figure 1). The observed rate of increase was $0.0029 \mathrm{mg}$ $\mathrm{L}^{-1}$ per $\mathrm{Mg}$ of gypsum applied. These increases certainly are associated with phosphorus content in the agricultural gypsum used, which comprised $7 \mathrm{~g}$ $\mathrm{kg}^{-1} \mathrm{P}_{2} \mathrm{O}_{5}$, since no important changes occurred in $\mathrm{P}-$ Mehlich and P-Rem before and after applications (Table 2). 
Figure 1. Variation in P levels in saturation extract as a function of gypsum doses applied on the surface.

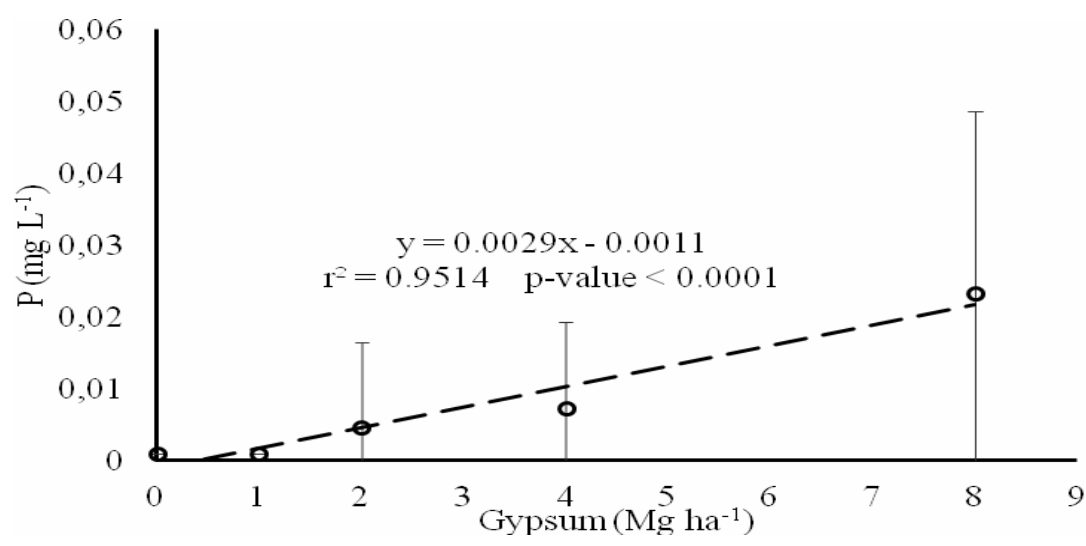

Table 2. Results of soil chemical analysis before correction and experiment installation.

\begin{tabular}{|c|c|c|c|c|c|c|c|c|c|c|c|c|c|}
\hline $\begin{array}{l}\mathrm{pH} \\
\mathrm{CaCl} 2\end{array}$ & $\begin{array}{l}\mathrm{pH} \\
\text { н2О }\end{array}$ & $\mathrm{Ca}^{2+}$ & $\mathrm{Mg}^{2+}$ & $\mathrm{K}^{+}$ & $\mathrm{H}^{+}+\mathrm{Al}^{3+}$ & $\mathrm{Al}^{3+}$ & $\begin{array}{c}\text { CEC } \\
\text { effective }\end{array}$ & $\begin{array}{c}\mathrm{CEC} \\
\mathrm{pH}_{7,00}\end{array}$ & $\begin{array}{l}\mathrm{V} \\
(\%)\end{array}$ & P-rem & $\mathrm{P}$ & $\mathrm{S}_{-} \mathrm{SO}_{4}$ & $\begin{array}{c}\mathrm{Vp} \\
\left(\mathrm{m}^{3} \mathrm{~m}^{-3}\right)\end{array}$ \\
\hline & & & 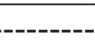 & ----- & $---\mathrm{cmol}_{\mathrm{c}}$ & $\mathrm{dm}^{-3}-$ & - & & & --------- & $-m g d r$ & 3 ----- & \\
\hline 5.09 & 5.58 & 8.84 & 2.33 & 0.37 & 6.39 & 0.00 & 11.54 & 17.94 & 64.32 & 19.66 & 12.46 & 5.13 & 0.2483 \\
\hline
\end{tabular}

$\mathrm{V}=$ Base saturation; P-rem = Remaining phosphorus; $\mathrm{Vp}=$ Volume of pores. Extractors: $\mathrm{KCl} 1 \mathrm{~N}\left(\mathrm{Ca}^{2+}, \mathrm{Mg}^{2+}, \mathrm{Al}^{3+}\right)$ Mehlich-1 $(\mathrm{P}$ and $\mathrm{K}), \mathrm{CH}_{3} \mathrm{COONH}_{4}\left(\mathrm{~S}_{-} \mathrm{SO}_{4}\right)$.

The application of agricultural gypsum up to $8.0 \mathrm{Mg} \mathrm{ha}^{-1}$ did not significantly change the $\mathrm{pH}$ of the soil or the levels of $\mathrm{Al}$ or Si. However, increases were noted in the $\mathrm{Ca}, \mathrm{Mg}, \mathrm{K}, \mathrm{P}$, and $\mathrm{S}$ levels (Tables 3, 4, 5, 6 and 7). These results agree with the observations of Leite et al. (2007), but are different from the results reported by Tavares Filho (2012), who did not note increases in the $\mathrm{Mg}$ and $\mathrm{K}$ levels in the saturation extract of a saline-sodic soil from Pernambuco, which received doses of mineral gypsum. The increase in $\mathrm{Ca}, \mathrm{Mg}, \mathrm{K}, \mathrm{P}$, and $\mathrm{S}$ levels can be explained by dissolution of gypsum, which contains $\mathrm{Ca}$ and $\mathrm{S}$, and by ion extraction at the colloidal surface caused by the high amounts of $\mathrm{Ca}$ added in the treatments. The mean values for $\mathrm{Ca}$ levels were adjusted in a linear model in both layers studied, with increases of $79.567 \mathrm{mg} \mathrm{L}^{-1}$ and 50.225 $\mathrm{mg} \mathrm{L}^{-1}$ per ton of gypsum in the 0-10 and 10-20 cm layers, respectively (Figure 2).

Table 3. Analysis of variance result ( $p$-value) of the evaluated variables.

\begin{tabular}{lccccccccc}
\hline Variation cause & $\mathrm{Ca}$ & $\mathrm{Mg}$ & $\mathrm{K}$ & $\mathrm{S}$ & $\mathrm{P}$ & $\mathrm{Al}$ & $\mathrm{Si}$ & $\mathrm{pH}$ & Conduct. \\
\hline Dose (D) & $<0.0001$ & $<0.0001$ & $<0.0001$ & $<0.0001$ & 0.0049 & 0.1882 & 0.059 & 0.0741 & $<0.0001$ \\
Depth (De) & $<0.0001$ & $<0.0001$ & $<0.0001$ & $<0.0001$ & 0.3799 & 0.068 & 0.4366 & 0.088 & $<0.0001$ \\
$\mathrm{D} \times \mathrm{De}$ & $<0.0001$ & 0.0448 & $<0.0001$ & $<0.0001$ & 0.843 & 0.106 & 0.9018 & 0.171 & 0.1382 \\
\hline
\end{tabular}


Table 4. Variation in average Ca levels $\left(\mathrm{mg} \mathrm{L}^{-1}\right)$ of soil saturation extract as a function of the surface-applied gypsum doses and sampling depth.

\begin{tabular}{cccccc}
\hline Depth & \multicolumn{5}{c}{ Gypsum doses $\left(\mathrm{Mg} \mathrm{ha}^{-1}\right)$} \\
\cline { 2 - 5 }$(\mathrm{cm})$ & 0 & 2 & 4 & 6 & 8 \\
\hline $0-10$ & $134.47 \mathrm{a}$ & $145.25 \mathrm{a}$ & $302.96 \mathrm{a}$ & $481.70^{\mathrm{a}}$ & $739.57 \mathrm{a}$ \\
$10-20$ & $65.79 \mathrm{~b}$ & $93.31 \mathrm{a}$ & $148.87 \mathrm{~b}$ & $251.24 \mathrm{~b}$ & $458.13 \mathrm{~b}$ \\
\hline $\mathrm{CV}(\%)=14.99$ & $\mathrm{MMD}=54.07$ & &
\end{tabular}

* Means followed by the same letter in the columns did not differ by Tukey test at $5 \%$.

Table 5. Variation in average $\mathrm{Mg}$ levels $\left(\mathrm{mg} \mathrm{L}^{-1}\right)$ of soil saturation extract as a function of the surface-applied gypsum doses and sampling depth.

\begin{tabular}{cccccc}
\hline Depth & \multicolumn{5}{c}{ Gypsum doses $\left(\mathrm{Mg} \mathrm{ha}^{-1}\right)$} \\
\cline { 2 - 5 }$(\mathrm{cm})$ & 0 & 2 & 4 & 6 & 8 \\
\hline $0-10$ & $31.21 \mathrm{a}$ & $35.414 \mathrm{a}$ & $50.66 \mathrm{a}$ & $68.52^{\mathrm{a}}$ & $90.01 \mathrm{a}$ \\
$10-20$ & $14.35 \mathrm{~b}$ & $24.08 \mathrm{~b}$ & $30.55 \mathrm{~b}$ & $51.09 \mathrm{~b}$ & $85.20 \mathrm{a}$ \\
\hline $\mathrm{CV}(\%)=12.23$ & $\mathrm{MMD}=7.52$ & &
\end{tabular}

* Means followed by the same letter in the columns did not differ by Tukey test at $5 \%$.

Table 6. Variation in average $\mathrm{K}$ levels $\left(\mathrm{mg} \mathrm{L}^{-1}\right)$ of soil saturation extract as a function of the surface-applied gypsum doses and sampling depth.

\begin{tabular}{cccccc}
\hline Depth & \multicolumn{5}{c}{ Gypsum doses $\left(\mathrm{Mg} \mathrm{ha}^{-1}\right)$} \\
\cline { 2 - 5 }$(\mathrm{cm})$ & 0 & 2 & 4 & 6 & 8 \\
\hline $0-10$ & $16.71 \mathrm{a}$ & $17.85 \mathrm{a}$ & $27.30 \mathrm{a}$ & $37.16^{\mathrm{a}}$ & $44.37 \mathrm{a}$ \\
$10-20$ & $11.27 \mathrm{a}$ & $19.33^{\mathrm{a}}$ & $22.53^{\mathrm{a}}$ & $53.91 \mathrm{~b}$ & $180.20 \mathrm{~b}$ \\
\hline $\mathrm{CV}(\%)=17.17$ & $\mathrm{MMD}=9.45$ & \multicolumn{5}{c}{} \\
\hline
\end{tabular}

* Means followed by the same letter in the columns did not differ by Tukey test at $5 \%$.

Table 7. Variation in average $\mathrm{S}$ levels $\left(\mathrm{mg} \mathrm{L}^{-1}\right)$ of soil saturation extract as a function of the surface-applied gypsum doses and sampling depth.

\begin{tabular}{cccccc}
\hline Depth & \multicolumn{5}{c}{ Gypsum doses $\left(\mathrm{Mg} \mathrm{ha}^{-1}\right)$} \\
\cline { 2 - 6 }$(\mathrm{cm})$ & 0 & 2 & 4 & 6 & 8 \\
\hline $0-10$ & $7.91 \mathrm{a}$ & $31.91 \mathrm{a}$ & $224.89 \mathrm{a}$ & $446.91^{\mathrm{a}}$ & $597.00 \mathrm{a}$ \\
$10-20$ & $7.12 \mathrm{a}$ & $27.08 \mathrm{a}$ & $65.43 \mathrm{~b}$ & $131.28 \mathrm{~b}$ & $226.47 \mathrm{~b}$ \\
\hline $\mathrm{CV}(\%)=16.84$ & $\mathrm{MMD}=38.01$ & \multicolumn{5}{c}{} \\
\hline
\end{tabular}

* Means followed by the same letter in the columns did not differ by Tukey test at $5 \%$.

In the $0-10 \mathrm{~cm}$ layer, the values of $\mathrm{Mg}, \mathrm{K}$, and $\mathrm{S}$ (Figures 3, 4, and 5), adjusted to second degree models, did not reach the maximum values at the tested doses. In the 10-20 cm layer, linear increases corresponding to $8.89,3.65$, and $28.068 \mathrm{~g} \mathrm{~L}^{-1}$ per $\mathrm{Mg}$ of gypsum were observed, respectively. 
Figure 2. Variation in Ca levels in saturation extract of the studied layers as a function of gypsum applied on the surface.

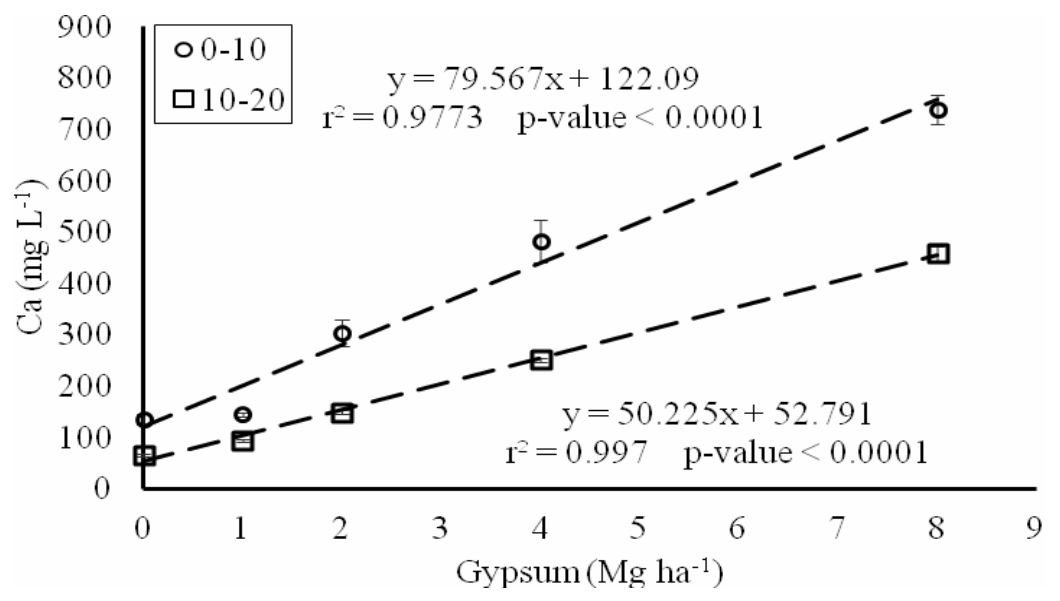

Figure 3. Variation in S levels in saturation extract of the studied layers as a function of gypsum applied on the surface.

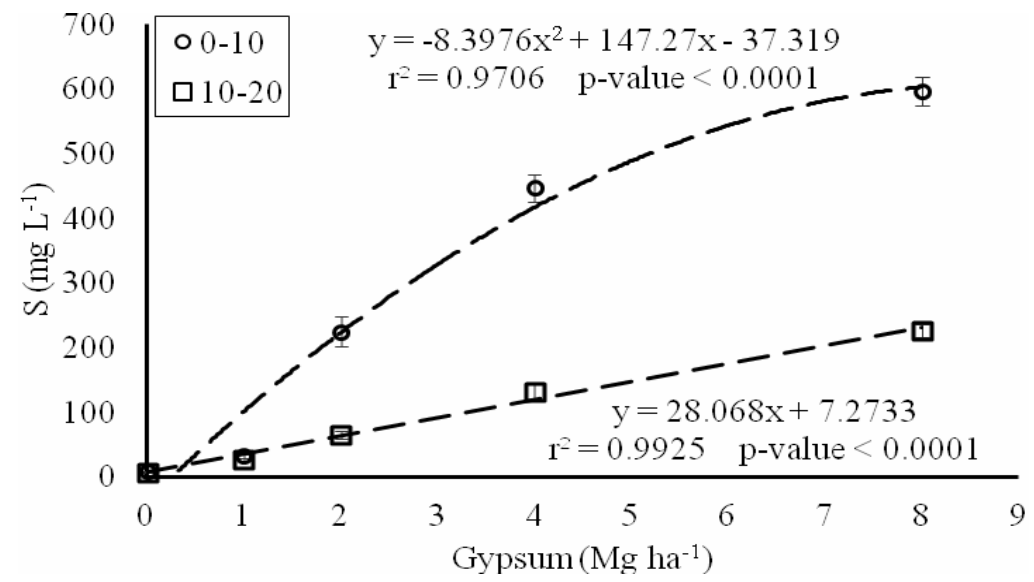

Figure 4 Variation in Mg levels in saturation extract of the studied layers as a function of gypsum applied on the surface.

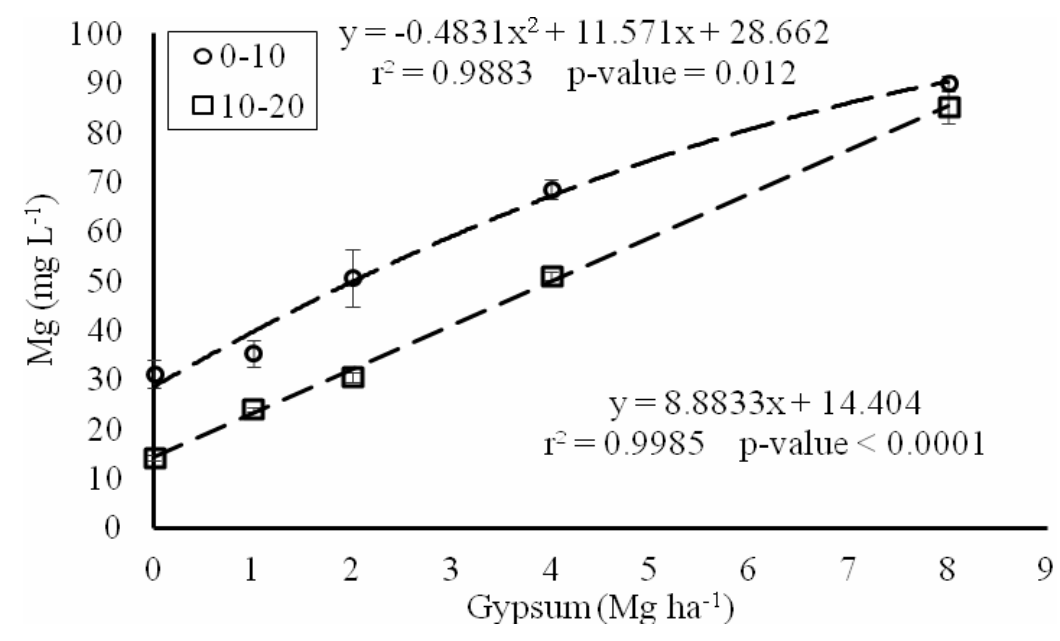


Figure 5. Variation in K levels in saturation extract of the studied layers as a function of gypsum applied on surface.

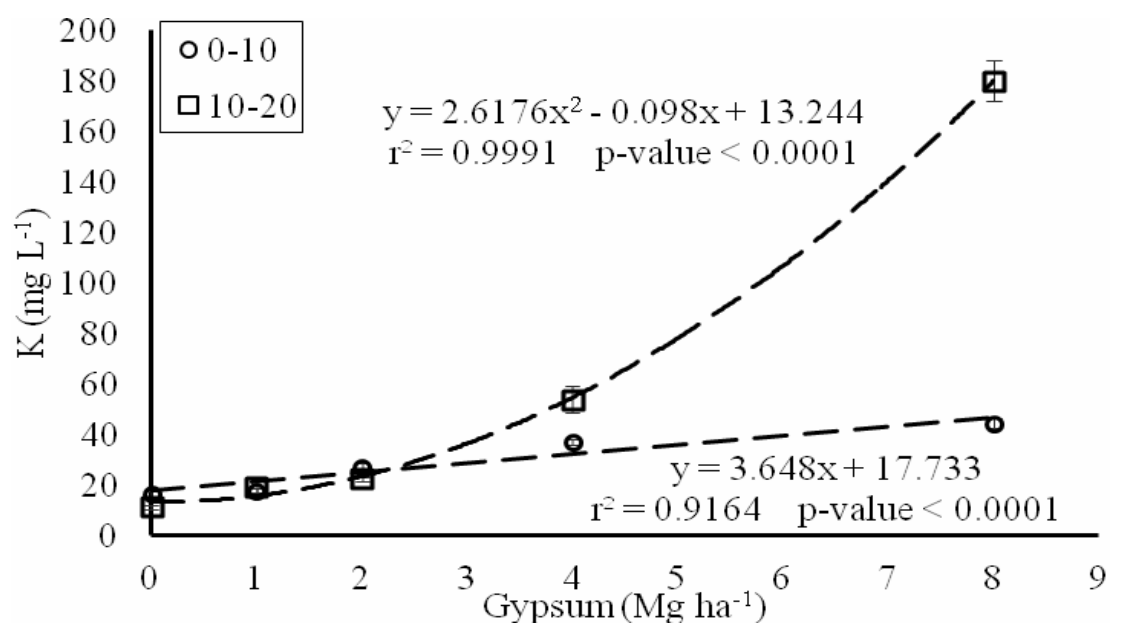

Consistent with the results obtained by Barros et the surface layer of 0-10 cm (Figure 6), while for al. (2009), the values of electrical conductivity in the saturation extract were significantly influenced by depth and gypsum dose, but without any interaction dose effect, the variation was greater, adjusted to a linear model, with an increase of $0.34677 \mathrm{mS} \mathrm{cm}^{-1}$ between them. The highest values were observed in per Mg of gypsum applied (Figure 7).

Figure 6. Values of electrical conductivity of the saturation extract at the studied depths.

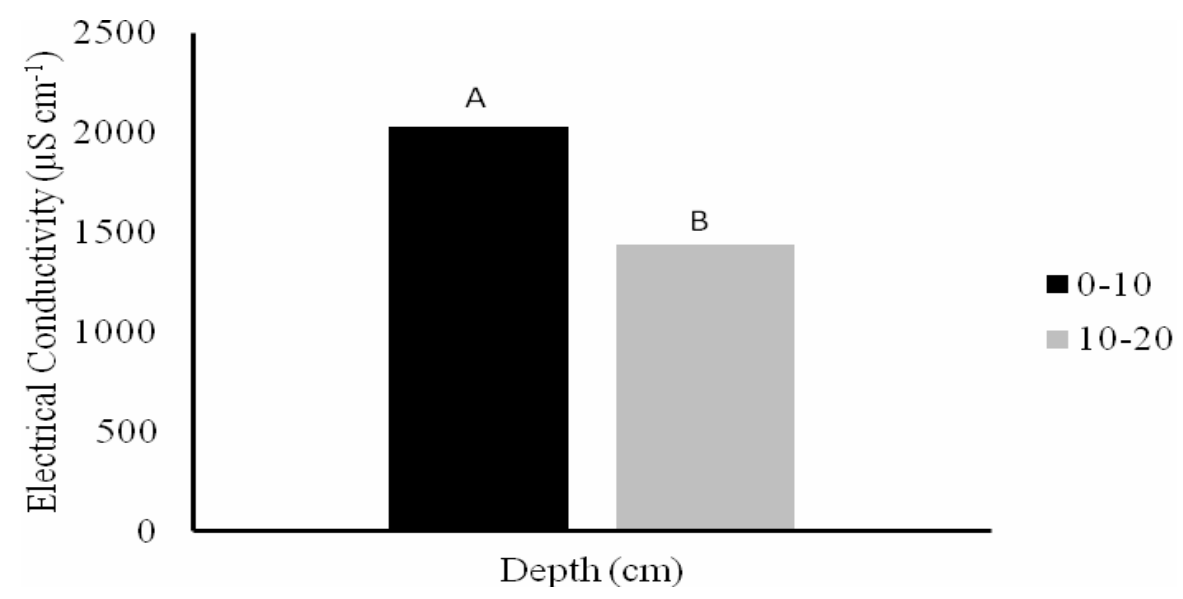


Figure 7. Variation in electrical conductivity of the saturation extract as a function of gypsum doses applied on the surface.

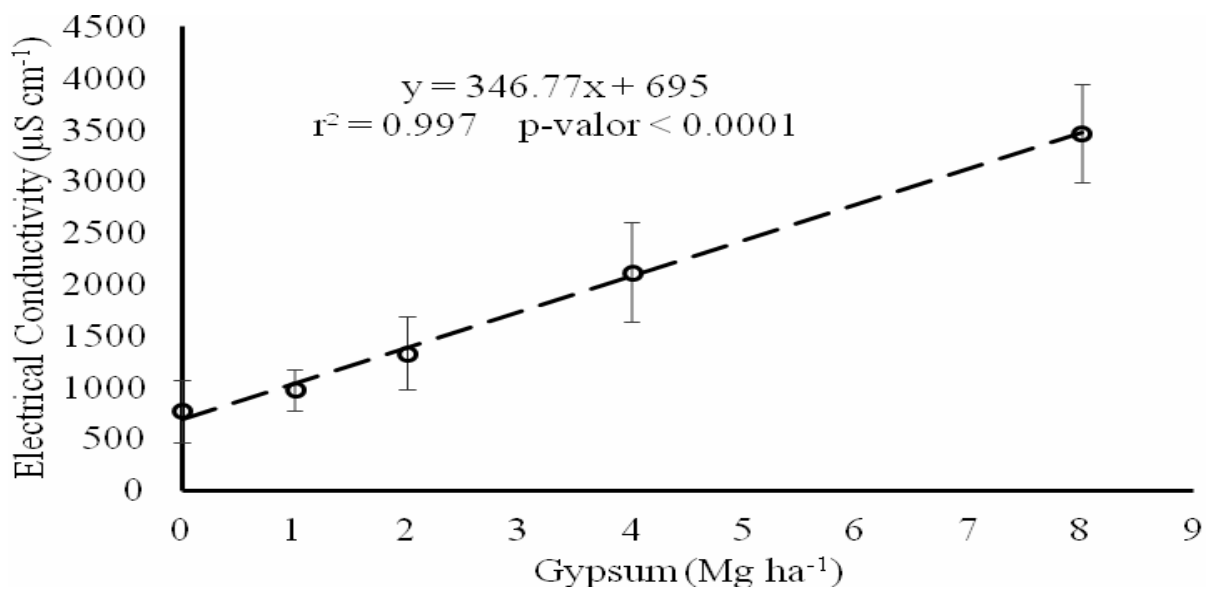

\section{Conclusion}

While $\mathrm{Al}$ and Si levels and $\mathrm{pH}$ of soil saturation extract were not affected, the $\mathrm{Ca}, \mathrm{Mg}, \mathrm{K}, \mathrm{P}$, and $\mathrm{S}$ levels increased in both layers as a function of surface application of agricultural gypsum.

After the application of gypsum, no changes were noted in the $\mathrm{Si}$ and $\mathrm{Al}$ levels and $\mathrm{pH}$ in the soil subsurface layer.

The electrical conductivity of soil saturation extract increased as a function of agricultural gypsum dose.

\section{References}

BARROS, M. de F. C.; BEBÉ, F. V.; SANTOS, T. O.; CAMPOS, M. C. C. Influência da aplicação de gesso para correção de um solo salino sódico cultivado com feijão caupi. Revista de Biologia e Ciências da Terra, João Pessoa, v. 9, n. 1, p. 77-82, 2009.

SIGINIFICADO DA SIGLA POR EXTENSO - CPRM. Medição in loco. Temperatura, $\mathrm{pH}$, condutividade e oxigênio dissolvido. Belo Horizonte: Manual CRPM, maio 2007.

FARINA, M. P. W.; CHANNON, P. Acid-subsoil amelioration: II. Gypsum effects on growth and subsoil chemical properties. Soil Science Society Journal of America, Madison, v. 54, n. 1, p. 175-180, 1988. Available at: $\quad<$ https://dl.sciencesocieties.org/publications/sssaj/ abstracts/52/1/SS0520010175>. Accessed at: 23 jun. 2015.

FORLONI, J. S. S. Produção de matéria seca do milho e fertilidade do solo em função da gessagem em excesso. Colloquium Agrariae, Presidente Prudente, v. 4, n. 2, p. 42-51, dez. 2008.

JALALI, M.; ROWELL, D. L. Potassium leaching in undisturbed soil cores following surface applications of gypsum. Environmental Geology, Reading, v. 57, n. 1, p. 41-48, 2009.

KINSEY, N. Hands-on agronomy. Revised \& expanded ed. Austin. Texas: Acres U.S.A, 2009. 394 p.

KORNDÖRFER, G. H. Gesso agrícola: adubos e adubação. Uberlândia: Instituto de Ciências Agrárias, 2008. Disponível em: <www.dpv24.iciag.ufu.br/new/ dpv24/Apostilas/Transp.-\%20S+GESSO\%2010.pdf . Acesso em: 16 nov. 2013.

LEITE, E. M.; CAVALCANTE, L. F.; DINIZ, A. A.; SANTOS, R. V.; ALVES, G. da S.; CAVALCANTE, I. H. L. Correção da sodicidade de dois solos irrigados em resposta à aplicação de gesso agrícola. Irriga, Botucatu, v. 12, n. 2, p. 168-176, 2007. Disponível em: <http://hdl. handle.net/11449/69582>. Acesso em: 23 jun. 2015.

MALAVOLTA, E. Manual de nutrição mineral de plantas. São Paulo: Agronômica Ceres, 2006. 638 p.

MARIA, I. C.; ROSSETTO, R.; AMBROSANO, E. J.; CASTRO, O. M.; NEPTUNE, A. M. L. Efeito da adição de diferentes fontes de cálcio no movimento de cátions 
em colunas de solo. Scientia Agricola, Piracicaba, v. 50, n. 1, p. 87-98, 1993.

MONTASER, A.; FASSEL, V. A. Inductively coupled plasma as atomization cells for atomic fluorescence spectrometry. Analytical Chemistry, Ames, v. 48, n. 11, p. 1490-1499, 1976.

PAVAN, M. A. Aplicação de alguns conceitos básicos da química na disponibilidade dos íons $\mathrm{Al}^{3+}$ para as plantas. Jaboticabal: SECITAP. FCAVJ/UNESP, 1984. 34 p.

RAIJ, B. V. Gesso na agricultura. Informações Agronômicas, Campinas, n. 122, p. 26-27, 2008.
SOUSA, D. M. G. de; LOBATO, E.; REIN, T. A. Uso de gesso agrícola nos solos do cerrado. Planaltina: Embrapa Cerrados, 2005. 19 p.

TAVARES FILHO, A. N.; BARROS, M. F. C.; ROLIM, M. M.; SILVA, E. F. F. e. Incorporação de gesso para correção da salinidade e sodicidade de solos salino-sódicos. Revista Brasileira Engenharia Agrícola Ambiental, Campina Grande, v. 16, n. 3, p. 247-252, 2012. Disponível em: <http://www. scielo.br/scielo.php? script $=$ sci_arttext\&pid $=$ S1415$43662012000300002 \& \operatorname{lng}=$ en\&nrm=iso $>$. Acesso em: 23 jun. 2015. 
